\title{
МЕХАНІЗМ ЗАПРОВАДЖЕННЯ ВЕНЧУРНОЇ ФІЛАНТРОПІЇ У КРАЇНАХ ІЗ ПОЧАТКОВИМ РІВНЕМ РОЗВИТКУ КУЛЬТУРИ БЛАГОДІЙНОСТІ (НА ПРИКЛАДІ УКРАЇНИ)
}

\author{
Чернівецький національний університет імені Юрія Федьковича
}

\begin{abstract}
Метою дослідження є запропонувати механізм запровадження венчурної філантропії у країнах із початковим рівнем розвитку культури благодійності, використавши приклад України.

При розв'язанні поставленого до дослідження завдання використано сукупність загальнонаукових та спеціальних методів дослідження, в тому числі логічного узагальнення та систематизації (для обгрунтування використання краудфандингового підходу для проектів, що не пройшли первинного конкурсного відбору в організації соціального впливу).

У статті обгрунтовано важливість застосування венчурного підходу до благодійності як такого, що допомагає вирішити основні причини наявних у суспільстві проблем. Зважаючи на початковий етап розвитку венчурної філантропії в Україні, запропоновано запроваджувати іiї у поєднанні 3 краудфандинговим підходом. Такий механізм сприятиме не лише швидшому запровадженню венчурної філантропії у вітчизняну практику благодійності, але і суттєвому підвищенню соціальної відповідальності НУО та громадян, що долучені до процесів.
\end{abstract}

Ключові слова: венчурна філантропія, неурядові організачії, організація сочіального впливу, інвестор для впливу, громадянське суспільство, краудфандинг.

\section{MECHANISM OF INTRODUCTION OF VENTURE PHILANTHROPY IN COUNTRIES WITH THE INITIAL LEVEL OF PHILANTHROPY CULTURE DEVELOPMENT (ON THE EXAMPLE OF UKRAINE)}

\author{
Yuriy Fedkovych Chernivtsi National University
}

The aim of the study is to propose a mechanism for introducing venture philanthropy in countries with an initial level of development of charitable culture, using the example of Ukraine.

A set of general scientific and special research methods, including logical generalization and systematization (to justify the use of crowdfunding approach for projects that have not passed the initial competitive selection in the organization of social impact) were used to solve the problem.

The article substantiates the importance of applying a venture approach to charity as one that helps to solve the causes of existing problems in society. The mechanism of venture philanthropy of European Venture Philanthropy Association (EVPA) is presented and described. It provides close interaction of investors for impact, social impact organization and beneficiaries.

As there is the initial stage of development of venture philanthropy in Ukraine, it is proposed to introduce it in combination with a crowdfunding approach. Such a mechanism will contribute not only to the faster introduction of venture philanthropy into charity practice, but also to a significant increase of the social responsibility of NGOs and citizens involved in the processes.

The originality of scientific research. It is the first time in Ukrainian practice when the peculiarities of venture philanthropy in Ukraine were investigated from a scientific point of view and it was proposed to use its flexibility to improve the charity process and increase the level of philanthropy culture in Ukraine. This can be achieved through a combination of venture and crowdfunding approaches to charity.

Keywords: Social responsibility, venture philanthropy, non-governmental organizations (NGOs), social impact organization, investor for impact, civil society, crowdfunding.

Постановка проблеми у загальному вигляді i iï зв'язок 3 важливими науковими та практичними завданнями. Зміна підходів до класичної філантропії була спричинена появою нової генерації бізнесменів, які прагнули розширити можливості 
впливу на навколишній світ за допомогою власної благодійної діяльності. Традиційно зміст філантропії передбачав спрямовування певної частини власних ресурсів благодійників (фізичних чи юридичних осіб) на досягнення досить вузьких цілей НУО зазвичай на основі одноразових пожертв чи надання однорічних грантів. Довготривала перспектива, інновації та ризики вважалися категоріями, притаманними великому бізнесу та несумісними з благодійною діяльністю. Новий підхід дав змогу розширити соціальний вплив благодійників та використати названі категорії при здійсненні благодійної діяльності.

Аналіз останніх досліджень, у яких започатковано вирішення проблеми. Вперше категорію «венчурна філантропія» застосував Дж. Д. Рокфеллер ще у 1969 р. під час своєї промови перед Американською Палатою Представників. Він пояснював її як творчий i ризикований підхід до філантропії. Проте наукова концепція венчурної філантропії вперше була запропонована лише в 1997 р. такими науковцями, як К. Летс, В. Раян та А. Гросман (C. Letts, W. Ryan, A. Grossman) [1]. Після цього до питань, пов'язаних із функціонуванням венчурної філантропії у своїх наукових дослідженнях зверталися як вітчизняні, так і зарубіжні науковці. Серед вітчизняних науковців варто відзначити праці таких вчених як Вигівська І., Гернего Ю. О., Гернего Ю. А., Кириленко О., Костенко С., Третяк М., Хоменко Г. Такі паці в основному були присвячені актуалізації запровадження венчурної філантропії як виду благодійності, дослідженню особливостей ії використання у зарубіжних країнах тощо. Серед зарубіжних вчених найбільш вагомим внеском у наукову думку характеризуються праці таких науковців: Etchart N., Davis L., Grenier H., Anheier H., Toepler S. Варто відзначити також, що закордоном функціонують організації, які не тільки здійснюють наукові дослідження венчурної філантропії, але і безпосередньо займаються нею на практиці. Прикладами таких організацій $є$ The Rockfeller Foundation, Toniic, LGT Venture Philanthropy, The European Venture Philanthropy Association та ін. Втім, як дослідження зарубіжних науковців, так і діяльність зазначених організацій в основному зосереджені на розвитку венчурної філантропії у країнах із розвиненою культурою благодійності.

Зважаючи на все вищесказане, актуалізовуються дослідження особливостей запровадження венчурної філантропії у країнах із початковим та перехідним рівнем розвитку культури благодійності.

Цілі статті. Запропонувати механізм запровадження венчурної філантропії у країнах із початковим рівнем розвитку культури благодійності, використавши приклад України.

Виклад основного матеріалу дослідження 3 повним обгрунтуванням отриманих наукових результатів. Механізм венчурної філантропії передбачає наявність так званого «інвестора для впливу» (як його прийнято називати в європейській практиці), який, зокрема, може бути представлений фондом соціального впливу. Інвестор для впливу, застосовуючи підхід венчурної філантропії до здійснення благодійності, спрямовує власні ресурси (фінансового і нефінансового характеру) на підтримку організацій соціального впливу. Такими організаціями найчастіше виступають соціальні підприємства, НУО (найчастіше громадські та благодійні організації) тощо.

Організації соціального впливу в своій діяльності визначають суттєві проблеми, зазвичай соціального характеру, на вирішення яких спрямовують власні зусилля та наявні у їх розпорядженні ресурси. Вирішення зазначених проблем не є ситуативним, а їх результати приносять вигоди довготривалого характеру кінцевим вигодонабувачам. Оскільки проблеми зазвичай не характеризуються локальним характером, то і групи вигодонабувачів $є$ доволі широкими. Вигодонабувачами можуть бути різноманітні 
меншини, представники вразливих соціальних груп, особи з обмеженими можливостями тощо.

У кінцевому підсумку інвестор для впливу може отримати соціальну і фінансову віддачу (остання найчастіше не носить прямий характер.)

Механізм власне венчурної філантропії подано на рис. 1.

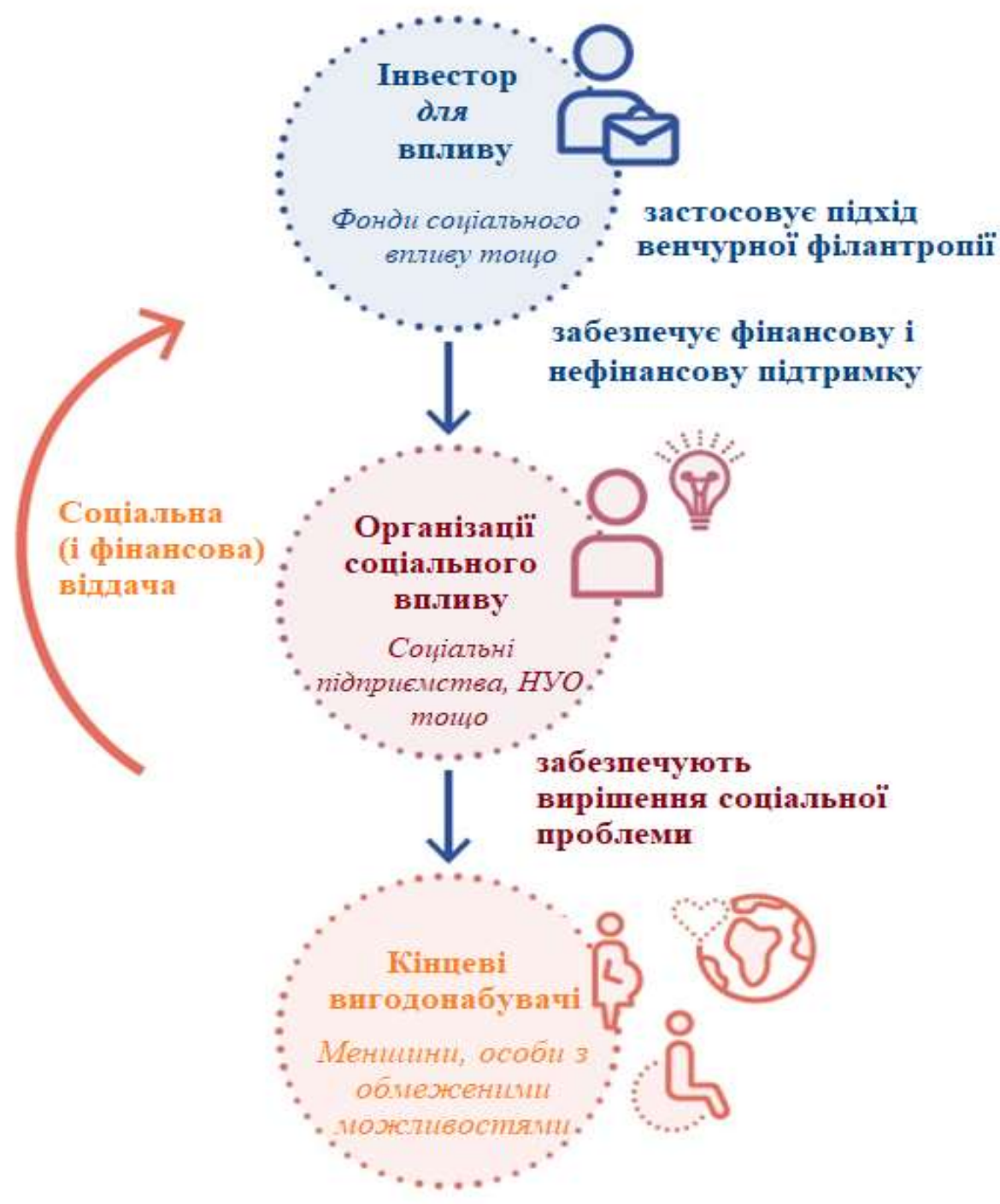

Рис. 1. Модель венчурної філантропії Європейської асоціації венчурної філантропії [2]

Таким чином, венчурна філантропія є механізмом благодійності, який вирішує не тільки проблеми вузької групи отримувачів благодійної допомоги (як у випадку традиційного підходу до благодійності), а створює переваги довготривалого характеру як для суспільства загалом, так і для самого інвестора для пливу.

Враховуючи вищесказане, Дж. Скотт пропонує розглядати венчурну філантропію як «грант соціальних змін», який має на меті вирішити причини «складних проблем» бідності, расизму, насильства тощо. Науковець зауважує, що з цією метою венчурна філантропія використовує низку взаємодоповнюючих підходів, серед яких називає 
організацію низових організацій (тобто розширення інституційної структури НУО), благодійність, пряме обслуговування, використання ЗМІ та залучення громадськості, а також політичну пропаганду [3, с. 7].

Венчурна філантропія є вже доволі розвиненим підходом до благодійності у світі, тому існує чимало успішних прикладів іiі реалізації. Організація SOPACT подає перелік організацій венчурної філантропії, які, на їх думку, мають найбільший вплив та $є$ найбільш успішними [4]. До цього переліку належать: «Toniik», «European Venture Philanthropy Association», «Venrure Philanthropy Partners», «LGT Venture Philanthropy».

«Toniic» - глобальна спільнота активних інвесторів для впливу. Своєю місією організація декларує поглиблення позитивного чистого впливу у всьому спектрі капіталу. В організації пояснюють, що всі інвестиції мають як позитивні, так і негативні наслідки (вони їх називають «впливом»). Таким чином, під «чистим позитивним впливом» розуміється переважання позитивного впливу над негативним. Тобто спільнота декларує прагнення інвестувати «там, де є спільний намір пом'якшити негативні наслідки та підкреслити позитивні, а також взяти на себе відповідальність за всі наслідки діяльності підприємства, а не лише ті, що відображені у традиційній фінансовій звітності» [5].

«European Venture Philanthropy Association» (EVPA). 3 моменту створення в 2004 p. працюють над створенням спільноти організацій, зацікавлених у практиці венчурної філантропії та соціальних інвестицій у всій Європі. EVPA визначає венчурну філантропію як підхід до створення сильніших організацій (шляхом надання їм як фінансової, так і нефінансової підтримки), що здійснюють інвестиції із суспільною метою [6].

«Venture Philanthropy Partners». Орієнтований на регіональну територію Великого Вашингтона та покращення життя дітей, партнери з венчурної філантропії застосовують високий підхід із залученням. Їх стратегія включає чотири етапи: ідентифікація партнерів, залучення, інвестиції та консультування [7].

«LGT Venture Philanthropy». LGT - це незалежна благодійна фундація, яка працює 3 організаціями, які безпосередньо сприяють досягненню цілі соціального розвитку. Окрім безпосереднього надання капіталу працюють 3 різноманітними об'єктами інвестування, щоб підтримати їх зростання та життєздатність. Кожна організація у портфелі LGT відповідає жорстким критеріям, включаючи узгодження місії та готовність до масштабування [8].

В той час, коли у економічно розвинених країнах світу венчурна філантропія стала звичним явищем, в Україні вона знаходиться лише на стадії започаткування та, так би мовити, осмислення, в тому числі, наукового. Про це свідчать кількість та зміст праць українських науковців, присвячених іiі дослідженню. Так, аналіз наукових публікацій, присвячених проблематиці венчурної філантропії, які знаходяться у вільному доступі, вказав не лише на малочисельність зазначених публікацій, а й на їх висвітлювальний характер. Тобто більшість 3 таких публікацій спрямовані на розкриття суті, змісту і актуальності такої форми благодійності (наприклад, [9,10, 11]).

Як відомо, наука та практика є певною мірою взаємообумовленими явищами, тому цілком логічним видається те, що венчурна філантропія в Україні знаходиться на початковому етапі свого становлення.

Нерозуміння глибинного змісту венчурної філантропії та iï принципових відмінностей від традиційного підходу до благодійності призвели до того, що у нашій державі до венчурної філантропії часто відносять різноманітні фонди, діяльність яких не спрямована на вирішення причин виникнення соціально-економічних проблем, а натомість - на ліквідацію чи на зменшення негативного впливу наслідків їх існування [12]. 
Втім, слід зауважити, що все ж існують позитивні приклади зародження венчурної філантропії у іiї найкращому виразі. Одним із позитивних прикладів є благодійний фонд «Кращим бути». Фонд засновано завдяки фінансовій та організаційній підтримці восьми підприємців-меценатів у м. Чернівці. Кращим бути - це «фонд, що об'єднує людей, які вболівають за своє місто». Головна мета діяльності благодійного фонду - «допомогти в реалізації проектів, що спрямовані на розвиток міста і громади» [13]. Благодійний фонд приймає та розглядає проекти за кількома напрямками «краще місто», «кращі люди», «кращий бізнес». Таким чином, благодійний фонд «Кращим бути» вирішує важливу суспільно проблему, притаманну для м. Чернівці, а саме: його діяльність спрямована на виведення міста із затяжної кризи, спричиненої політичними війнами, міжклановою боротьбою та організаційною неспроможністю представників органів місцевого самоврядування.

Хочемо наголосити, що венчурна філантропія є тим механізмом, який, завдяки власній гнучкості, дає змогу застосовувати в комплексі й інші способи та підходи до благодійності. У благодійному фонді «Кращим бути» використовують підхід схожий за змістом на краудфандингове фінансування. Оскільки загальна сума фінансування, що виділяється на реалізацію проектів в межах одного конкурсу є обмеженою, то опис тих проектів, які не знайшли необхідної підтримки серед членів журі (якими є інвестори та партнери), розміщується на сайті благодійного фонду (не на краудфандинговій платформі), де всі охочі можуть підтримати їх реалізацію фінансово, виступивши, так званими, донорами / бекерами (залежно від типу проекту). Як і у випадку використання краудфандингових платформ, якщо автори проекту не змогли знайти необхідної підтримки, а проект не зібрав необхідну суму коштів для реалізації, то всі зібрані кошти повертаються донорам / бекерам.

На нашу думку, підхід, коли проекти, які потребують фінансової підтримки, розміщуються не на краудфандинговій платформі, а на власному сайті організації соціального впливу (благодійного фонду, ГО та ін.), має певні переваги. До таких переваг відносимо більшу можливість контролю зі сторони інвесторів для впливу за збором та подальшою реалізацією проектів, а також певну економія коштів для авторів проектів (краудфандингові платформи, у випадку успішного збору всієї необхідної суми для реалізації проектів, знімають певні комісійні (наприклад, на платформі «Спільнокошт» плата за користування платформою складає 10 \% від зібраних коштів [14]), що передбачено договором про фінансування). Втім, такий підхід має суттєвий недолік: як зазначає, одна із засновників благодійного фонду «Кращим бути» Оксана Лелюк, ще жоден проект, який був розміщений на власному сайті фонду для збору фінансування, не зібрав необхідної суми.

Зважаючи на вищесказане, вважаємо, що організаціям соціального впливу, які використовують венчурний підхід до благодійності, варто співпрацювати 3 добре перевіреними краудфандинговими платформами. В Україні такими платформами $є$ «Спільнокошт» [14], «На-Старті» [15], «GoFundEd» [16], «StartWay» [17].

Графічно весь процес можна зобразити як на рис. 2. 


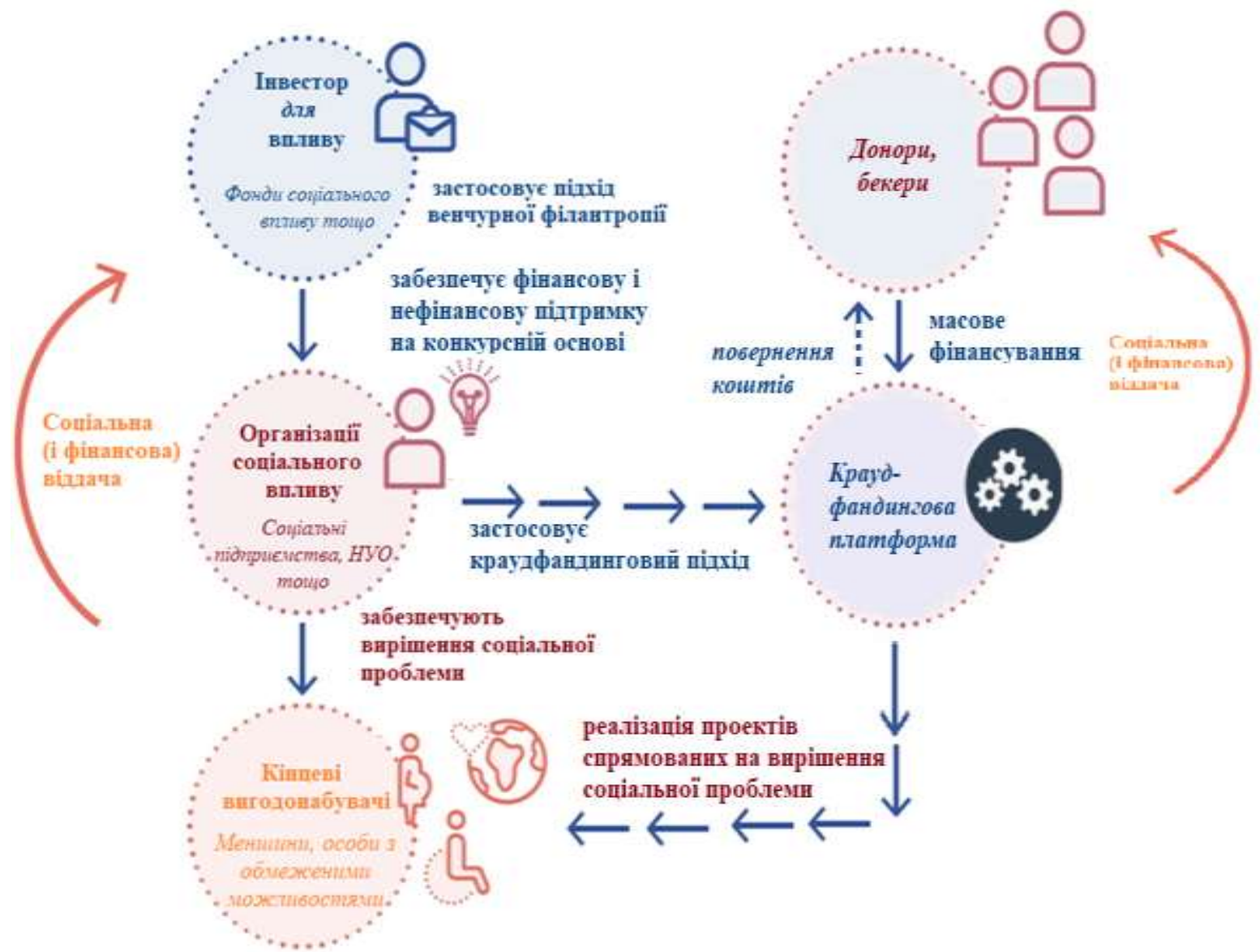

Рис. 2. Поєднання венчурного та краудфандингового підходів у благодійності* *Побудовано автором

Рис. 2. пояснює можливість поєднання венчурного та краудфандингового підходів (з використанням існуючих краудфандингових платформ) до благодійності у країнах, які перебувають на початковому етапі розвитку венчурної благодійності. Венчурними інвесторами визначається загальна сума, яку вони передають організації соціального впливу для розподілу на конкурсній основі для реалізації проектів спрямованих на вирішення конкретної соціально-економічної проблеми. Венчурні інвестори або їх представники безпосередньо беруть участь у відборі проектів, які отримають фінансування (така участь демонструє безпосереднє залучення венчурних інвесторів у процес, в подальшому вони сприяють реалізації проектів-переможців). Ті проекти, що не отримали схвалення при первинному відборі на конкурсній основі не відхиляються автоматично, a, за бажання авторів проектів, розміщуються на краудфандинговій платформі. Венчурні інвестори та організації соціального впливу сприяють поширенню інформації про проекти задля залучення більшої кількості донорів / бекерів. У випадку збору необхідної суми коштів, авторами реалізовуються проекти, спрямовані на вирішення пріоритетної для організації соціального впливу соціальноекономічної проблеми.

Використання зазначених платформ не лише дасть змогу залучити кошти на фінансування проектів з більшою ймовірністю (адже зазначені платформи $є$ відомими, розміщені на них проекти легше рекламувати та просувати за допомогою соціальних мереж. Більше того, багато соціально активних громадян заходять на ці платформи цілеспрямовано задля того, щоб ознайомитися з розміщеними проектами та обрати один чи кілька для фінансування), але й надасть інші переваги для організацій соціального 
впливу, інвесторів та авторів проектів, які не отримали фінансування при первинному конкурсному відборі.

Перш за все мова про безпеку як для організації соціального впливу, так і для донорів / бекерів, які хочуть підтримати певний проект. Зміст цієї переваги полягає в тому, що краудфандингові платформи є більш захищеними та стійкими до різноманітних хакерських атак, адже в їхній захист інвестується значна сума коштів.

Іншою перевагою для авторів проекту $є$ наявність професійних менеджерів та адміністраторів платформ, завдяки яким ці платформи завжди є активними, а отже, залучення потенційних донорів / бекерів є простішим технічно.

Ще однією суттєвою перевагою, яку надає використання професійних краудфандингових платформ авторам проектів пов'язана із самим змістом краудфандингу. Вона полягає в тому, що для кожного окремого проекту зазначаються необхідна сума фінансування та період часу, за який цю суму необхідно зібрати. При цьому, якщо за визначений період часу авторам проекту вдається зібрати більшу за визначену суму коштів, то вони отримують всю суму (за виключенням комісії за користування краудфандинговою платформою). Таким чином, автори проектів мають можливість залучити значно більші суми для їх реалізації $[18,19]$.

Організації соціального впливу, які пропонують авторам подальше розміщення власних проектів на краудфандингових платформах, теж отримують низку переваг. Перш за все, мова про економію людських та фінансових ресурсів на адмініструванні просування проектів, які не отримали фінансування на конкурсній основі.

Ще однією перевагою $\epsilon$ популяризація діяльності згаданих організацій соціального впливу завдяки збільшенню кількості реалізованих проектів, а також, як наслідок, сприяння досягнення основної мети їх діяльності (у випадку благодійного фонду «Кращим бути» сприяння розвитку міста Чернівці).

Іншою суттєвою перевагою для організацій соціального впливу є збереження позитивної репутації перед авторами проектів та потенційними донорами / бекерами. Автори проектів отримують більше можливість для їх реалізації. Водночас, потенційні донори / бекери, у випадку неуспішної кампанії по збору коштів, при поверненні власних внесків втрату їх частини (яка пов'язана із комісією платіжної системи і складає близько 2 \%-2,5 \%), не пов'зують із назвою та діяльністю конкретної організації соціального впливу.

Переваги, які отримують організацій соціального впливу та автори проектів, у випадку використання краудфандингової платформи відображено на рис. 3 .

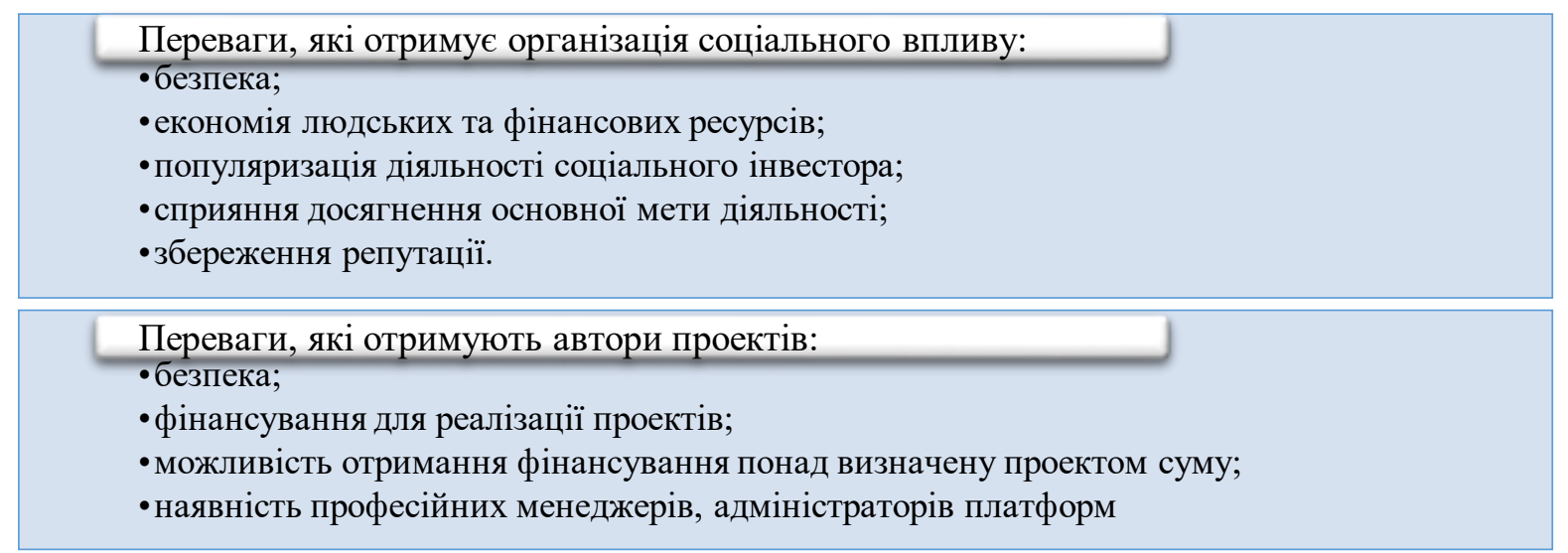

Рис. 3. Переваги від використання краудфандингових платформ для дофінансування проектів, які не отримали первинної фінансової підтримки венчурних інвесторів*

*Побудовано автором 
Висновки. Отже, венчурна філантропія $є$ принципово новим підходом до благодійності, який дає змогу використовувати інструменти венчурних інвесторів у процесі забезпечення досягнення системних змін.

У економічно розвинених державах світу такий підхід до благодійності $\epsilon$ надзвичайно популярним. Водночас в Україні він проходить процес становлення. Зважаючи на це, а також на початковий етап розвитку культури благодійництва в Україні загалом, у вітчизняній практиці для активізації процесів розвитку венчурної філантропії варто запроваджувати іiі у поєднанні з краудфандинговим підходом. Такий механізм сприятиме не лише швидшому запровадженню венчурної філантропії у вітчизняну практику благодійності, але і суттєвому підвищенню соціальної відповідальності НУО (організацій соціального впливу та інших організацій, що з ними співпрацюють задля вирішення соціально-економічної проблеми) та громадян, що долучені до процесів.

\section{Список бібліографічного опису}

1.Letts C., Ryan W., Grossman A. Virtuous Capital: What Foundations Can Learn from Venture Capitalists. Harvard Business Review. 1997. March-April 1997 Issue. URL: https://hbr.org/1997/03/virtuous-capital-what-foundations-can-learn-fromventure-capitalists.

2.EVPA. Offiacial site. URL: https://evpa.eu.com.

3. Grenier P. Venture philanthropy in Europe: obstacles and opportunities. European Venture Philanthropy Association. 2006. URL: http://www.psm.org.mx/wp-content/uploads/downloads/VenturePhilanthropyinEuropeObstaclesandOpportunities.pdf. 4.Examples of venture philanthropy organizations / Sopact. URL: https://www.sopact.com/venture-philanthropy.

5.Toniic. Official site. URL: https://toniic.com.

6.About EVPA / European Venture Philanthropy Association. Official site. URL: https://evpa.eu.com/about-us/about-evpa.

7.Venrure Philanthropy Partners. Official site. URL: https://www.lgtvp.com/en.

8.LGT Venture Philanthropy. Official site. URL: https://www.lgtvp.com/en.

9.Вигівська, І. М., Хоменко, Г. Ю. Сучасний механізм венчурного фінансування соціальних проектів у конфліктні часи: обліковий вимір. «Вісник ЖДТУ»: Економіка, управління та адміністрування. 2018. № 4 (86). С. 43-47.

10. Гернего, Ю. О., Гернего, Ю. А. Інвестиційна природа венчурної філантропії: сутнісні характеристики та майбутнє. Модернізація економіки: сучасні реалії, прогнозні сценарії та перспективи розвитку: матеріали I Міжнародної науково-практичної конференції (25-26 квітня $2019 \quad$ p., м. Херсон). URL: https://ir.kneu.edu.ua/bitstream/handle/123456789/32578/Ger_19_4_3.pdf?sequence=1.

11. Хоменко Г. Ю. Розвиток венчурної філантропії в умовах гібридної війни напрями вдосконалення облікового забезпечення. Проблеми теорії та методології бухгалтерського обліку, контролю і аналізу. 2019. №3 (44). URL: http://pbo.ztu.edu.ua/article/view/195582/195972.

12. Занина, А. А. Венчурная филантропия: сущность и основные принципы функционирования. Вісник студентського наукового товариства ДонНУ імені Василя Стуса. 2014. № 2 (6). С. 113-118.

13. Кращим бути. Благодійний фонд. Офіційний сайт. URL: http://bestbe.cv.ua.

14. Спільнокошт. Офіційний сайт. URL: https://biggggidea.com.

15. Na-starte. Official site. URL: https://web.archive.org/web/20170807215330/http://na-starte.com/about.

16. GoFundEd. Official site. URL: https://gof.org.ua.

17. StartWay. Official site. URL: https://start-way.com.ua/uk.

18. Ткачук I. Я. Фінансове забезпечення діяльності громадських організацій України: наукова монографія. Чернівці : Технодрук, 2016. 272 C.

19. Ткачук І. Я. Краудфандинг в контексті залучення додаткових ресурсів для реалізації проектів державноприватного партнерства. Інноваційна економіка. 2016. № 5-6. С. 183-186.

\section{References}

1. Letts C., Ryan W., Grossman A. Virtuous Capital: What Foundations Can Learn from Venture Capitalists. Harvard Business Review. 1997, March-April 1997 Issue. Available at: https://hbr.org/1997/03/virtuous-capital-what-foundations-can-learnfrom-venture-capitalists.

2. EVPA. Offiacial site. Available at: https://evpa.eu.com.

3. Grenier P. Venture philanthropy in Europe: obstacles and opportunities. European Venture Philanthropy Association, 2006. Available at: http://www.psm.org.mx/wp-

content/uploads/downloads/VenturePhilanthropyinEuropeObstaclesandOpportunities.pdf.

4. Examples of venture philanthropy organizations, Sopact. Available at: https://www.sopact.com/venture-philanthropy.

5. Toniic. Official site. Available at: https://toniic.com.

6. About EVPA, European Venture Philanthropy Association. Official site. Available at: https://evpa.eu.com/about-us/aboutevpa.

7. Venrure Philanthropy Partners. Official site. Available at: https://www.lgtvp.com/en.

8. LGT Venture Philanthropy. Official site. Available at: https://www.lgtvp.com/en.

9. Vyhivska, I. M., Khomenko, H. Yu. Suchasnyi mekhanizm venchurnoho finansuvannia sotsialnykh proektiv u konfliktni chasy: oblikovyi vymir. «Visnyk ZhDTU»: Ekonomika, upravlinnia ta administruvannia, 2018, Vol. 4 (86). pp. 43-47. [in Ukrainian]. 
10. Herneho, Yu. O., Herneho, Yu. A. Investytsiina pryroda venchurnoi filantropii: sutnisni kharakterystyky ta maibutnie. Materialy I Mizhnarodnoi naukovo-praktychnoi konferentsii "Modernizatsiia ekonomiky: suchasni realii, prohnozni stsenarii ta perspektyvy rozvytku", Kherson, 2019, Available https://ir.kneu.edu.ua/bitstream/handle/123456789/32578/Ger_19_4_3.pdf?sequence=1. [in Ukrainian].

11. Khomenko H. Yu. Rozvytok venchurnoi filantropii v umovakh hibrydnoi viiny napriamy vdoskonalennia oblikovoho zabezpechennia. Problemy teorii ta metodolohii bukhhalterskoho obliku, kontroliu i analizu. 2019, Vol. 3 (44). Available at: http://pbo.ztu.edu.ua/article/view/195582/195972. [in Ukrainian].

12. Zanina, A. A. Venchurnaia fylantropyia: sushchnost y osnovnye pryntsypy funktsyonyrovanyia. Visnyk studentskoho naukovoho tovarystva DonNU imeni Vasylia Stusa, 2014, Vol. 2 (6), pp. 113-118. [in Russian].

13. Krashchym buty. Blahodiinyi fond. Official site. Available at: http://bestbe.cv.ua.

14. Spilnokosht. Official site. Available at: https://biggggidea.com.

15. Na-starte. Official site. Available at: https://web.archive.org/web/20170807215330/http://na-starte.com/about.

16. GoFundEd. Official site. Available at: https://gof.org.ua.

17. StartWay. Official site. Available at: https://start-way.com.ua/uk.

18. Tkachuk I. Ya. Finansove zabezpechennia diialnosti hromadskykh orhanizatsii Ukrainy: naukova monohrafiia. Chernivtsi. Tekhnodruk, 2016. 272 p. [in Ukrainian].

19. Tkachuk I. Ya. Kraudfandynh v konteksti zaluchennia dodatkovykh resursiv dlia realizatsii proektiv derzhavno-pryvatnoho partnerstva. Innovatsiina ekonomika, 2016., Vol. 5-6, pp. 183-186. [in Ukrainian].

Дата подання публікації 02.09.2020 р.

\title{
УДК 339.92
}

Туролєв Г. О., аспірант

Turolyev G. O., post graduate student ДВНЗ «Київський національний економічний університет імені Вадима Гетьмана» https://orcid.org/0000-0001-5579-0626

\section{ГЛОБАЛІЗАЦЙНН ТЕНДЕНЦІЇ РОЗВИТКУ ОФШОРНОГО БАНКІНГУ}

\author{
ДВНЗ «Київський національний економічний університет імені Вадима Гетьмана»
}

Глобальні умови функціонування світової банківської системи закладають якісно нові умови акумулювання і перерозподілу фінансового капіталу за різними регіонами і секторами світової економіки, а також трансформації сукупних заощаджень економічних агентів різних країн у глобальний інвестиційний капітал. Особливе місце у світовій банківській архітектурі посідає офшорне банківництво, яке в останні десятиліття перетворилось на усталений й невід'ємний компонент глобального фінансового ринку. Охоплюючи операції банківських установ, що локалізовані в офшорних юрисдикціях, офшорний банкінг забезпечує підприємницьким структурам значне послаблення податкового навантаження, високу конфіденційність комерційних угод та надійне збереження капіталу. У той самий час поглиблення міжнародної спеціалізації і виробничого кооперування, фрагментація глобальних потоків товарів i капітальних ресурсів забезпечують економічним суб'єктам широкі можливості щодо застосування послуг офшорного банківського бізнесу у цілях використання особливих систем корпоративного законодавства. У статті розкрито масштаби і структурну динаміку офшорного банківництва в останні десятиліття. Комплексно охарактеризовано сучасні тенденції розвитку офшорних банків 3 акцентуванням дослідницького інтересу на процесах системної технологізації і динамічному поширенні фінтеху і штучного інтелекту, проникнення у даний сектор технологій електронної комерції, його переведення на технології блокчейну, посилення клієнт-орієнтованості і персоніфікованості офшорних банківських операцій, глибокої конвергенції діяльності офшорних банків й міжнародних інвестиційних компаній, активізації злиттів трастових офшорних компаній та ін. Доведено, що дані тенденції відбивають глобальний характер діяльності офшорних банків, високий рівень інноваційності їх сервісів, неухильну диверсифікацію банківських послуг та підвищення рівня стійкості банківської системи до дії чинників світової економічної нерівноваги. Особливу увагу приділено питанню щодо реалізації блокчейн-стартапів та організації бірж з торгівлі цифровими валютами, що справляють вагомий вплив на механізми функціонування офшорного банківництва. Обгрунтовано, що клієнтам офшорних банків надається на сьогодні широкий спектр послуг, що виходить далеко за рамки власне банківського обслуговування, й 